\title{
Transdisciplinary Research: Collaborative Leadership and Empowerment Towards Sustainability of Push-Pull Technology
}

\author{
Isaac Mbeche Nyang'au 1,2,*, Girma Kelboro ${ }^{1}$, Anna-Katharina Hornidge ${ }^{3,4}$, \\ Charles A. O. Midega ${ }^{2}$ and Christian Borgemeister ${ }^{1}$ \\ 1 Center for Development Research (ZEF), University of Bonn, Genscherallee 3, D-53113 Bonn, Germany; \\ gmensuro@uni-bonn.de (G.K.); cb@uni-bonn.de (C.B.) \\ 2 International Centre of Insect Physiology and Ecology (ICIPE), P.O. Box 30772-0100 Nairobi, Kenya; \\ cmidega@icipe.org \\ 3 Institute of Sociology, University of Bremen, 28334 Bremen, Germany; \\ anna-katharina.hornidge@leibniz-zmt.de \\ 4 Leibniz Center for Tropical Marine Research (ZMT), Fahrenheitstr 6, 28359 Bremen, Germany \\ * Correspondence: imbeche@icipe.org; Tel.: +254-799615194
}

Received: 4 April 2018; Accepted: 4 July 2018; Published: 9 July 2018

\begin{abstract}
A transdisciplinary research approach requires that different scientists with their discipline-specific theories, concepts and methods find ways to work together with other societal players to address a real-life problem. In this study, the push-pull technology (PPT) was used as a boundary object to enable interactions among stakeholders across science-practice boundaries engaged in the control of stemborer pest in maize crops in Bako Tibe, Jimma Arjo and Yayu Woredas in Ethiopia between August 2014 and April 2015. The PPT is a biological mechanism developed by researchers for the control of stemborer pests and Striga weed in maize crop. It involves inter-cropping maize with a stemborer moth-repellent silverleaf or greenleaf Desmodium (push), and planting an attractive trap crop, Napier or Brachiaria grass (pull), around it. The on-farm implementation of PPT was used to provide an opportunity for collaboration, interaction and learning among stakeholders including researchers from the Ethiopian Institute of Agricultural Research and practitioners from the Ministry of Agriculture and smallholder farmers/traders. The research was implemented following the transdisciplinary action research and the data collected using mixed methods approach, including key informant interviews, focus group discussions, workshops, on-farm practical demonstrations and participant observations. The findings show that collaborative leadership provides a chance for the stakeholders to participate in the technology learning and decision making, by enabling them to jointly contribute skills towards development, refinement and adaptation of the PPT. In situations where there are conflicts, they are embraced and converted to opportunities for in-depth learning, finding solutions and adaptation of the innovation processes rather than being sources of contradictions or misunderstandings. The leadership roles of the farmers enabled them to reflect on their own practices and draw on scientific explanations from researchers. It also enabled them to take the lead in new technology implementation and information sharing with fellow farmers and other stakeholders in a free and easy manner. Although the perennial nature of the companion crops in the PPT provides opportunities for continuous stakeholder interaction and learning, it requires a personally committed leadership and formal institutional engagements for the sustainability of the activities, which span several cropping seasons. Market forces and the involvement of the private sector also play a role as shown from the involvement of individual farmers and traders in Desmodium and Brachiaria seed production, collection and distribution during the PPT implementation.
\end{abstract}


Keywords: collaboration; leadership; push-pull technology; sustainability; transdisciplinary research; Ethiopia

\section{Introduction}

The uptake of academic research into policy and practice requires the input and active participation of other societal stakeholders. In transdisciplinary research, participation of non-academic or lay persons bring a large range of knowledge and expertise which is vital to the research process where it is framed and conducted with flexibility [1]. It is almost impossible to ignore transdisciplinarity when engaging in sustainability research and vice versa. These approaches are aimed at generating knowledge to solve societal challenges such as poverty, climate change leading to drought or less regular rainfall, increased incidences of pests, diseases and weeds, rising food prices, conflicts, etc. [2]. These challenges cannot be resolved by individuals, one community or a country alone. Addressing them requires joint efforts from multiple disciplines, groups, and organizations. That means the challenges require new ways of knowledge generation and decision making through the involvement of diverse stakeholders including those from outside academia [ibid.]. The process is promising when these approaches have clearly set out goals and competent management to facilitate creativity, innovation and management of conflicts which may exist or arise out of the stakeholder engagement [3]. Participation of non-academics contributes to democratizing the research process, thereby enabling production of better and socially more robust research outputs [4-7]. The knowledge production processes become democratized to the extent that the dominant and non-dominant actors have-at least temporarily_equal access and ability to contribute towards solving societal challenges [8].

Transdisciplinary research aims at establishing a form of collaboration which empowers stakeholders to influence the research, to question and to modify the dominant structures which guide epistemic processes [9]. In other words, the process enhances mutual learning for knowledge production between researchers and other stakeholders, and to bring about the empowerment of the participants either through education on areas of interest or to have their agenda and perspectives integrated in the knowledge production process [10]. Such an authentic and inclusive participation empowers the stakeholders to become better agents of change in their communities from problem identification to finding solutions [11,12]. This model of research in sustainability studies embraces a sequence of stakeholder engagement and involvement from informing to consulting, to collaborating and to empowerment where practitioners are able to implement the research findings [13,14]. In this case, empowerment is seen as a process of providing stakeholders with the space to make decisions right from research planning to the use of the findings. Such an empowerment is bound to take place when it is linked with leadership and innovation [15].

Transdisciplinary leadership comes in handy when stakeholder engagement and interaction is mediated towards fruitful collaborations at the level of boundary-crossing [16,17]. Although the diverse sets of stakeholders are brought together by a common societal problem, in practice they are still ascribed to different disciplinary, organizational and institutional silos [18]. Leadership with collaborative approach plays an important role in trying to overcome some of these boundaries across different agencies or agency units [19-23]. It is recommended that, to make progress in tackling the common problems, all these stakeholders take on the leadership challenge of building shared-power arrangements $[13,16]$. Such empowerment and leadership should not be motivated by personal power needs, but the potential through which stakeholder collaboration can be used to address common societal problems for mutual benefits [24]. A collaborative leader, therefore, has a responsibility to provide guidance, coordinate the transdisciplinary research process and ensure that the other stakeholder groups participate in making decisions and taking actions in a democratic atmosphere to address the problem at hand. According to Gray, such a leader is equated with a transformative leader who can combine cognitive, structural, and processual tasks: 
The task of effective cognitive leadership is to provide a vision and commitment that link and motivate the scientific researchers to step beyond their disciplinary silos, relax old assumptions, and search for creative frame-breaking solution. Effective structural leadership adds value by breaking the gaps existing between science and practice through building bridges. Effective processual leadership task encourages trust and turns potentially destructive conflicts into constructive and participatory interactions. ([18], p. 9)

Studies on transdisciplinary collaboration show that there is progress in connecting and integrating the knowledge with action to support the research agenda, decision making and governance and sustainable use of natural resources and climate change adaptation [14,25-29]. Evaluation of these studies shows that contextual factors either at individual or collective levels greatly contribute to influencing the communicative and collaborative readiness of the teams and chances for success of the transdisciplinary work $[23,28]$. The presence or absence of institutional support for cross-disciplinary collaboration, the disciplinary specialization and mandates of the research centers, prior cooperation experiences of the research team members in working with other stakeholders, availability of logistical support in cases where the research sites and teams are in distant locations, etc. are some of these factors. The more aligned they are at the beginning of the transdisciplinary research, the greater is the prospect for success in terms of effective and sustainable transdisciplinary collaboration [23]. It is acknowledged that the individuals within the research teams with collaborative management skills appear to make a difference between success and failure in transdisciplinary efforts from their charismatic personality, leadership, knowledge base, broad network and engagement [30]. Such individuals have the ability to anticipate challenges during the transdisciplinary process, learn from failures in case they happen, and be flexible in the process and prepared to adapt to new conditions within the overarching objective of addressing the problem at hand [3]. Collaboration among the stakeholders is instrumental to ensure that their engagement and interactions worked in terms of learning and effective implementation of agricultural innovations. Such innovative processes on joint innovation implementation require leadership with strong advocacy at scientific research and practice levels and, at the same time, willingness to play a central role in the promotion of a free and divergent thinking, risk taking, and readiness to challenge the established methods, theories and practices [30]. That means the transdisciplinary stakeholder collaboration contributes to the empowerment and leadership skill enhancement of especially smallholder farmers so that they can effectively conduct and implement research findings and train others do it [14] To illustrate and show this in practice, this paper is using the experiences on the introduction and implementation of a new technology dubbed as push-pull technology (PPT) in the Oromia region of Ethiopia.

In Ethiopia, extension staffs tend to serve as agents of centralized political power in their respective Woredas or Kebeles. In the course of their work, they are mostly engaged in delivering political messages and undertaking tasks on behalf of the ruling party, such as collecting taxes under the cover of extension work [31]. However, few initiatives have been used to facilitate collaboration among the researchers and other stakeholders in the strengthening of agricultural innovation and networks in the country. For example, it has been shown that a strong partnership between national research and extension systems with regional administrations, cooperative unions, the private sector and farmers can be effectively put to work [32]. This was done during the promotion of high-value and market-oriented grain legumes (i.e., common beans, chickpeas and lentils). The so-called Agriculture Development-Led Industrialization (ADLI) economic growth strategy is spearheaded by the Government of Ethiopia to enhance crop and livestock productivity, increase the commercialization of smallholder surpluses, enhance accessibility of credit to smallholders and facilitate grassroot participation in development projects for poverty reduction [33]. The participatory extension system within the ADLI framework is aimed at building the capacity of the smallholder farmers to solve their production challenges, raise their income and develop management skills to improve their lives by using their own local resources. It has been reported that, through this extension approach, farmers have been trained on standard land preparation and management practices, the benefits of applying fertilizer, usage of improved seeds, cultural practices in control of pests, etc. The approach has seen about $1 \%$ expansion of cultivated area, 
and, with favorable weather conditions, agricultural production rose by $5.4 \%$ and grain yield increased from $<1$ to $2 \mathrm{t} /$ ha in 2013/2014 [34]. However, this is merely rhetoric. To sustain such production levels and achieve food and nutrition security in the country, the Ethiopian agriculture sector require continuous investment in research and extension for the generation, promotion and adoption of new and production enhancing technologies [35].

The transdisciplinary research approach is seen in principle as an opportunity for empowerment by bestowing confidence in the farmers and making their views, knowledge and skills shared with other farmers, but also researchers and extension professionals on an equal basis. The new skills learned and knowledge generated from such interactions are meant to inform further research and practice. The paper reports the findings of our study which addressed the questions of how collaborative leadership and empowerment work in transdisciplinary research in practice in the context of smallholder farmers and what to consider to enhance the processes.

\subsection{The Operationalization of Key Terms Used in This Study}

Agricultural Innovation refers to the development or adoption of new agricultural technologies, concepts or ideas, and/or successful exploitation of new ideas. It also embraces the totality and interaction of actors involved in the development of the ideas [36] (p. 7).

Boundary objects refers to those objects which are both plastic enough to adapt to local needs and constraints of the several parties employing them, yet robust enough to maintain a common identity across sites. This is an analytical concept of those scientific objects which both inhabit several intersecting social worlds and satisfy the informational requirements of each of them [37] (p. 393).

Transdisciplinary Research (TDR) refers to the researchers and other societal players working together by integrating their knowledge and perspectives into a shared problem definition to solve a real-life problem $[23,38,39]$. In this paper, TDR is operationalized to refer to joint efforts of research scientists consisting of entomologists, chemical ecologists, weed scientists, social scientists, and other stakeholders consisting of farmers, traders, extension service providers (public or private sectors), input suppliers, Non-Governmental Organizations (NGOs), community-based organizations and farmer groups/associations working together in the PPT implementation.

Push-Pull Technology (PPT) refers to a cropping strategy for controlling stemborer pests and the parasitic Striga weed in maize where it is intercropped with a stemborer moth repellent fodder legume, Desmodium (the push) and with an attractant trap plant, such as Napier grass (the pull) planted around the intercropped cereal [40]. In this paper, the PPT is operationalized as a boundary object.

Stakeholders refers to a person, group or organization who have interest or concern and are affected by the innovation or their activities strongly affect the performance of the innovation [39]. In this paper, stakeholders include researchers, farmers, traders, extension service providers (public or private sectors), input suppliers, NGOs, community-based organizations and farmer groups or associations.

\subsection{The push-pull Technology}

In Ethiopia, based on the Central Statistical Agency [41], maize accounts for $28 \%$ of the total cereal production compared to sorghum (22\%), and teff (20\%) [41]. Smallholder farmers in Ethiopia account for $>90 \%$ of the total agricultural production and $95 \%$ of total maize area with an average yield of about $2.5 \mathrm{t} /$ ha $[32,42]$ which is well below the yield potential of over $5 \mathrm{t} /$ ha [43]. Higher productivity in the maize sector could propel Ethiopia's food production and would enable the country to reduce its national food deficit and keep pace with a growing population. However, production is severely constrained by stemborer pests and parasitic weeds, particularly Striga, and low soil fertility [44,45]. Stemborers alone can result in significant yield losses ranging $10-80 \%$ of the total maize yield, depending on pest population density and phenological stage of the crop at infestation [46]. Stemborer control is, however, difficult, largely as a result of the cryptic and nocturnal habits of moths, and protection provided by host stem for immature pest stages [47]. The control measures mostly advised by research and extension 
services to smallholder farmers are based on the use of synthetic insecticides, which is not only harmful to the environment but often too expensive for smallholder farmers [48]. The push-pull technology offers an ecological approach for effective pest and weed management based on a combined use of interand trap cropping systems where stemborers are driven away from maize crops by push plants (push) and attracted by and trapped on trap plants (pull), and where the parasitic Striga weeds are effectively controlled through root exudates from the Desmodium plants [49].

In the PPT strategy, a cereal crop such as maize is intercropped with a stemborer moth repellent fodder legume, Desmodium (the push), together with an attractant trap plant, Napier/Brachiaria grass (the pull), planted around the maize-legume intercrop (Figure 1). The green leaf volatiles produced by Desmodium repel stemborer moths while those produced by the trap grasses attract them [40]. In addition, Napier or Brachiaria grasses greatly reduce the development of the stemborer larvae and hence the majority of them die before reaching adulthood [50]. Desmodium root exudates also suppress and eliminate Striga, leading to significantly enhanced maize/cereal yields [51]. Studies have identified the mechanisms by which Desmodium suppresses Striga, with an allelopathic effect being the most important one [52]. Desmodium roots produce a blend of chemical compounds, some of which stimulate Striga seeds to germinate while others inhibit lateral growth of Striga roots, thereby hindering their attachment to maize roots, i.e., suicidal germination [52-54]. Striga emergence is thus suppressed, with an in situ reduction of the Striga soil seed bank]. In addition, the PPT is beneficial in crop-livestock integration through fodder provision (by the grass and legume companion plants), soil improvement, agro-ecosystems resilience through crop intensification, income generation and meeting food security demands of smallholder farmers [55]. Currently about 200,000 farmers are practicing the PPT in East Africa [56]. Although the PPT concurrently addresses both the Striga weed and stemborer pests, Striga was not considered as a serious threat by the farmers in the study areas. The PPT implementation (Table 1) was undertaken on these areas where stemborer pests was identified as the most challenging in maize crop production constraint.

Table 1. Study area and location of the push-pull technology (PPT) demonstration plots.

\begin{tabular}{|c|c|c|c|c|c|c|c|}
\hline \multicolumn{8}{|c|}{ Study Area and Location of the PPT Demonstration Plots } \\
\hline Zone & Woreda & Kebele & AEZ & $\begin{array}{l}\text { Location of the } \\
\text { Plots }\end{array}$ & Altitude & $\begin{array}{l}\text { Longitude } \\
\text { (N) }\end{array}$ & $\begin{array}{l}\text { Latitude } \\
\text { (E) }\end{array}$ \\
\hline \multirow{2}{*}{ West Shawa } & \multirow{2}{*}{ Bako Tibe } & Dembi Gobu & Mid-land & Gibe river & 1660 & $09^{\circ} 09.173^{\prime}$ & $037^{\circ} 02.131^{\prime}$ \\
\hline & & Seden Kite & Mid-land & Leku river & 1648 & $09^{\circ} 05.331^{\prime}$ & $037^{\circ} 09.847^{\prime}$ \\
\hline \multirow{2}{*}{ East Wollega } & \multirow{2}{*}{ Jima Arjo } & Wayu Kumba & High land & Nageso river & 1990 & $08^{\circ} 46.442^{\prime}$ & $036^{\circ} 31.616^{\prime}$ \\
\hline & & Wayu Kumba & High land & Nageso river & 1986 & $08^{\circ} 46.582^{\prime}$ & $036^{\circ} 32.554^{\prime}$ \\
\hline \multirow{2}{*}{ Ilu-Ababora } & \multirow{2}{*}{ Yayu } & Jame Shono & High land & Sky-sky & 1904 & $08^{\circ} 21.353^{\prime}$ & $035^{\circ} 36.584^{\prime}$ \\
\hline & & Jame Shono & High land & Jame-Bone & 1870 & $08^{\circ} 21.351^{\prime}$ & $035^{\circ} 57.736^{\prime}$ \\
\hline
\end{tabular}

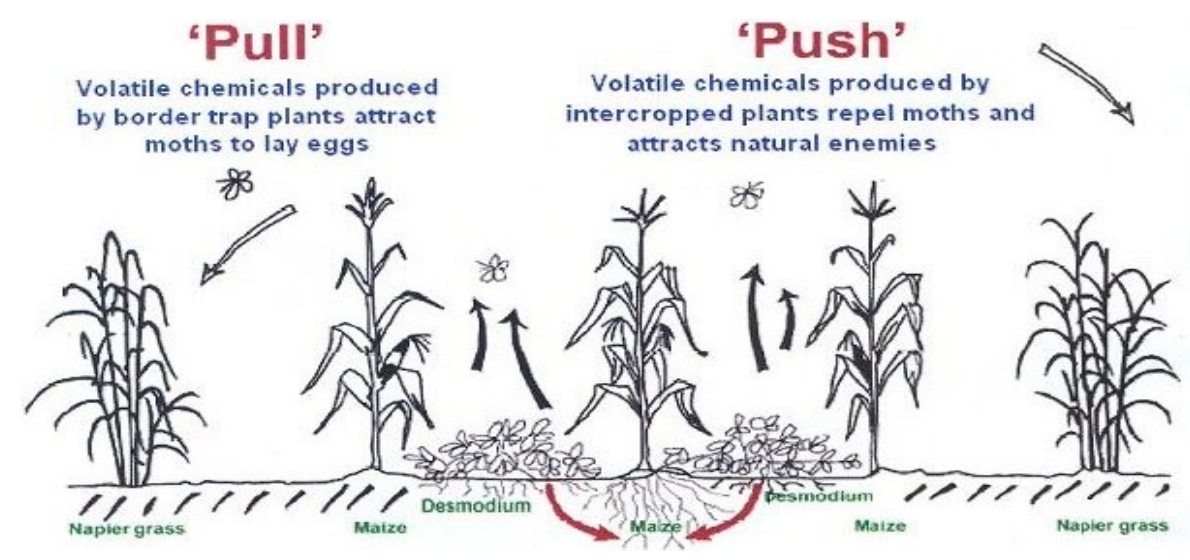

Figure 1. How push-pull technology works [56]. 


\section{Methodology: Transdisciplinary Action Research}

The implementation of the study was based on transdisciplinary action research (TDR) $[23,25]$ and drawing on the experiences of the Follow the Innovation (FTI) approach which was developed by the Center for Development Research (ZEF) in the context of Uzbekistan's agriculture $[57,58]$. The action research design is an interactive, collaborative and rigorous iterative process which engages practitioners in managing systematic enquiries to improve their practices and better realize their desired outcomes and contribute effectively towards the longer-term goals [59,60]. It is a systematic (Figure 2) and participatory paradigm that supports transdisciplinary reflective learning, communication and co-operation between the different stakeholders in the learning and knowledge production for addressing the real-life problems, developing innovative solutions and incorporating them in new action strategies $[23,25,61]$.

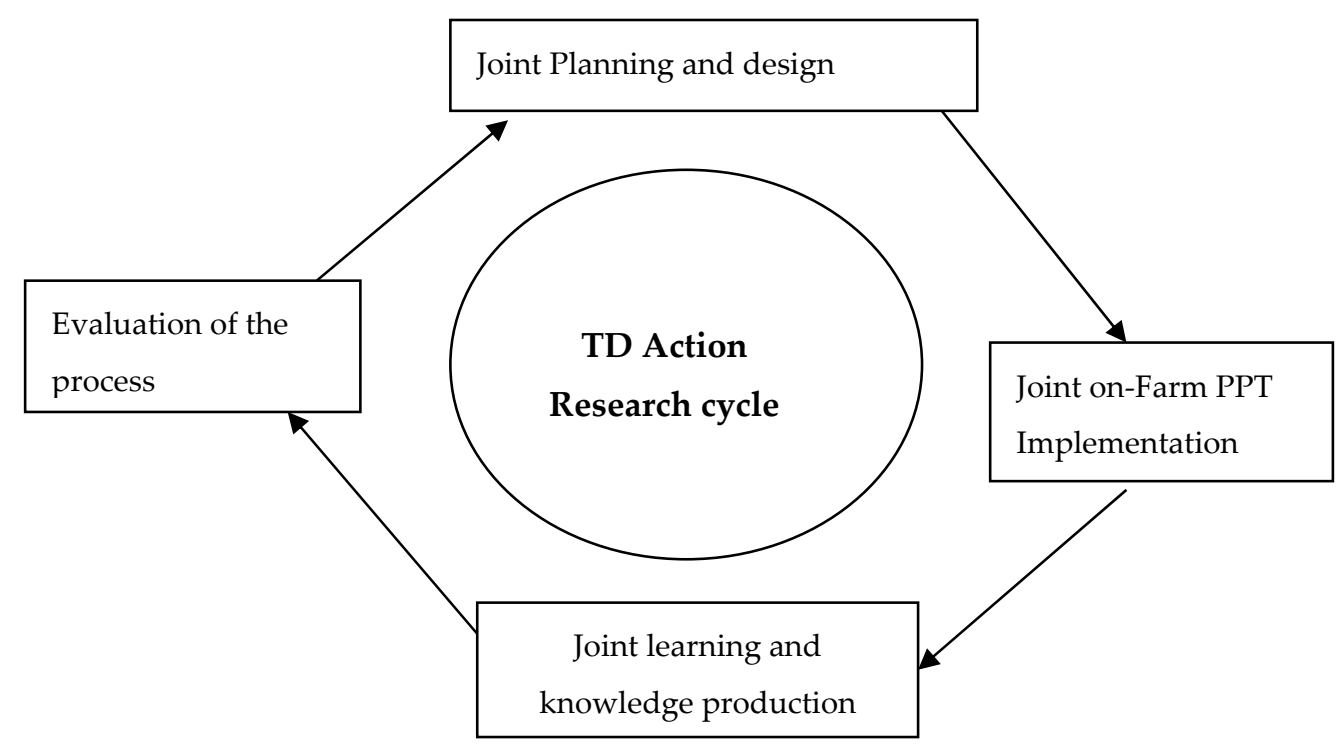

Figure 2. Transdisciplinary (TD) action research cycle.

As a joint process, the transdisciplinary action research was used as a strategy to enable learning among the farmers, researchers and other stakeholders, to share their knowledge and experiences towards the production of locally adaptable knowledge $[56,62]$ and, in this particular case, on the control of stemborer pests and parasitic weeds in maize. The team of researchers consisted of an entomologist, chemical ecologist, weed scientist, and social scientist, whereas other stakeholders included farmers, agro-dealers, public extension service providers and smallholder farmers. The TDR is premised on good communication between researchers and other stakeholders to ensure that knowledge sharing, and learning takes place with eventual empowerment and development of new knowledge or practices. The PPT implementation followed the stepwise practical on-farm activities of maize crop agronomic and management practices; land preparation, planting, weeding, harvesting of either as green maize cobs for roasting or dry cobs for grains, harvesting Desmodium and Brachiaria plants as fodder for livestock and seeds. After the harvesting of the maize, the process involved off-cropping season activities mainly on the process evaluation of the learning outcomes and any impacts achieved.

\subsection{Research Design and Data Collection Methods}

\subsubsection{Research Design}

The research process started with stakeholder identification and organizing planning workshops at the regional, Woreda and farmer levels. The identified stakeholders were selected based 
on their professional and organizational mandates, research and disciplinary specializations, or because they were in positions of influencing decision making or had interest in finding a lasting solution to the stemborer problems in cereal crops such as maize. Some of the stakeholders were researchers/agronomists from the University of Jimma, Ethiopian Institute of Agricultural Research (EIAR) and the Jimma Plant Health Clinic. Other stakeholders were crop protection experts from the Federal Ministry of Agriculture (MoA), agronomists, extensionists and crop protection experts from the Oromia Regional Bureau of Agriculture and zonal agricultural offices, journalists (Fana Radio and Oromia Television) and the maize growing smallholder farmers.

The first workshop was conducted at the regional level, whereas the follow-up workshops were conducted at the Woreda and farmer levels. During these workshop, the discussions centered on how the use of the PPT as an innovation can be used to address the problem of stemborer pests and also as an opportunity for collaboration and joint learning by exploiting the technical expertise, knowledge and the experiences from the stakeholders (research, farmers and extension service providers). Although the PPT concurrently address both Striga weed and stemborer pests, Striga was not considered as serious threat by the farmers in the study areas. The practical PPT implementation, field observations, joint learning and evaluation took place at farm level and involved participatory collaboration and engagement of the transdisciplinary research team in undertaking the PPT activities. Facilitation of the process by the researchers played a key role of ensuring that there was a balanced participation during discussions and in managing potential biases or conflicts. This was aimed at ensuring that knowledge and concerns of all the stakeholders were consolidated during the implementation of the research. The facilitation considered the consent to participate and confidentiality of the information shared by the stakeholders.

\subsubsection{Data Collection}

In the data collection process, different qualitative methods were used. The process engaged 37 Key Informant (KI) interviews, 16 Focus Group Discussions (FGD), 2 stakeholder workshops, on-farm practical demonstration and Participant Observations (PO) to assure triangulation. The study lasted for eight months from August 2014 to April 2015. The KI interviewees were mainly researchers, extension and administration officers from the ministries and farmer leaders. The FGD participants were the PPT farmers and their neighbors. The PO were based on the researchers' observation during on-farm practical demonstrations and workshop discussions to document observations on the attitudes, behaviors and actions of the participants.

The interviews were guided and focused on: knowledge and the background information on the stemborer pests' problem in maize crop and effect on yield; type of pest control measures commonly applied and their effectiveness; how the PPT management was similar or different from local farming practices; and new opportunities, practices and knowledge gained and challenges faced in the course of the PPT implementation. The implementation of PPT in terms of its sustainability was discussed. The data were transcribed into themes which were analyzed and interpreted in relation with the research objective. The analysis was guided by an innovation systems approach [36,63-66] by exploring how different actors collaborate and work together during technology implementation; and manage boundaries by integrating their knowledge bases through joint learning and communication. The approach helped to draw the attention of different stakeholders who contributed to the PPT implementation, by focusing on their roles and responsibilities, actions and interactions.

\subsection{The Study Area}

The study was implemented in three Woredas in the Oromia Region of western Ethiopia, namely Bako Tibe, Jimma Arjo and Yayu (Figure 3). These sites were identified in Ethiopia using a GIS based "hot-spot" approach by African and German partners of the BiomassWeb project (https://biomassweb.org). The Woredas are located in the western parts of Oromia and were selected as the potential "maize growing basket" of Ethiopia $[67,68]$ in which the "livelihood of local 
communities ( . . ) traditionally stands on household-based subsistence agriculture, extensive use of forests and cultivation on considerably small plots of agricultural land with an average of one hectare of cropland mainly for the cultivation of staple cereals such as maize, teff and wheat" [69] (p. 10). The soils in the areas are severely degraded due to nutrient depletion and/or poor in organic matter from continuous mono-cropping and unsustainable farming practices. Insect pests, principally stemborers, are major cereal production constraints [70-72]. According to Hurni [73], the area is characterized predominantly by bi-modal rainfall, with short rains in March and April, and long rains from June to October, with a distinct dry season extending usually from November to February. The dominant soil types are Nitosols with fertile alluvial soils in valley bottoms and depressions. Major crops, in order of importance, are maize, teff, pepper, sorghum, millet and pulses. In Yayu, coffee is an important cash crop. The farming system is mixed crop-livestock based.

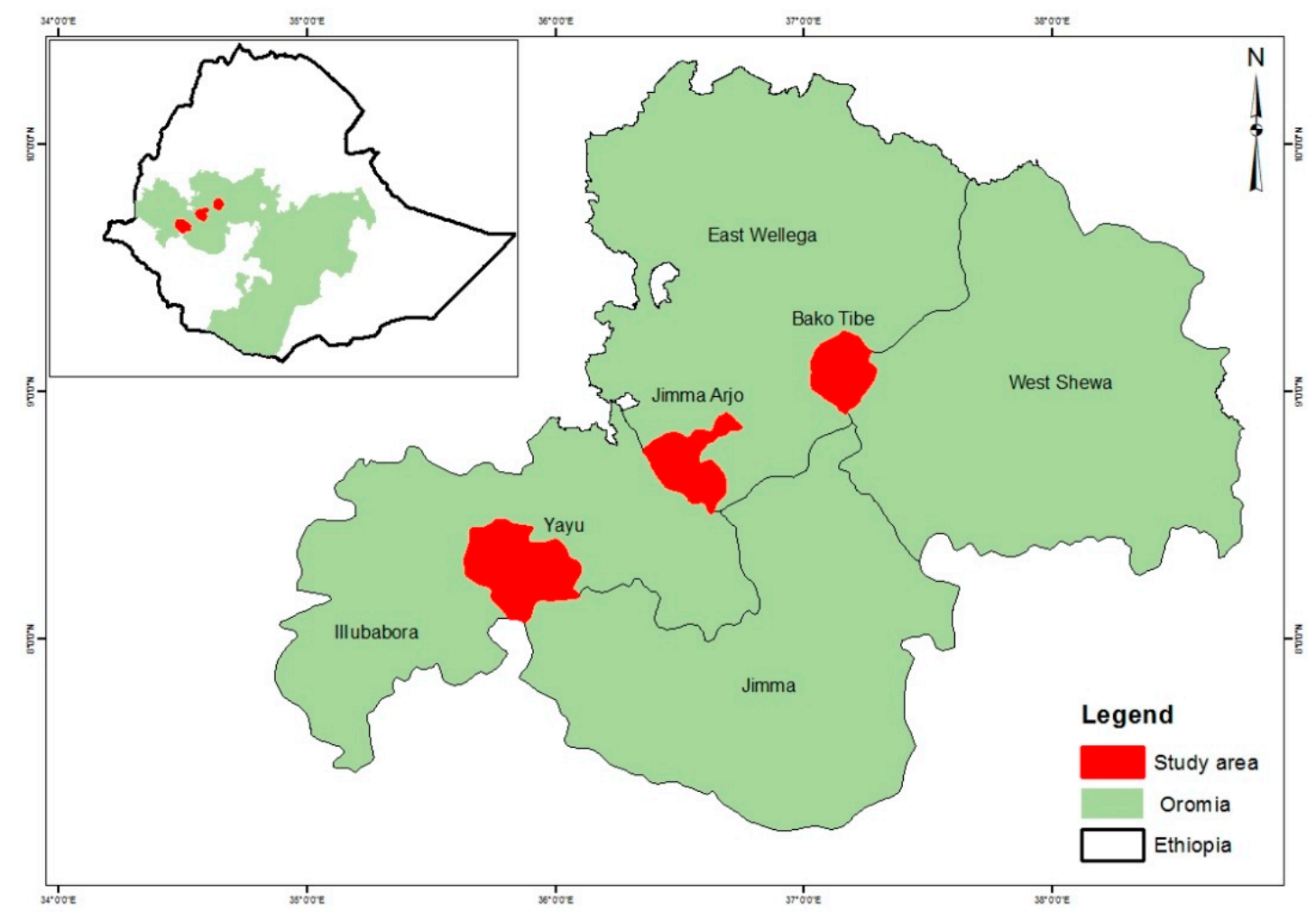

Figure 3. Map of the study area in western Oromia, Ethiopia.

\section{Findings}

\subsection{The Benefits}

3.1.1. Transdisciplinary Collaboration as an Opportunity for Farmers Empowerment to Take Up Leadership Roles

The PPT planning and implementation process was undertaken based on a joint and collaborative environment during workshops and on-farm discussions and activities, where the researchers and other stakeholders interacted, contributed and applied their knowledge and practices on how the PPT activities could address the problem of stemborer pests and other challenges such as availability of fodder for livestock, soil and water conservation. During the processes, the researchers' contributions were driven by their scientific knowledge mainly from laboratory and on station research experiments. Farmers and extension staff contributions were based on their experiential and day-to-day encounters with the stemborer pests and other farming challenges at farm level. In the conventional research-extension-farmers linkages, the farmers are regarded the recipients of the 
already tested and ready-to-use knowledge or practices. However, joint stakeholder implementation of the PPT was a different approach involving the collaboration between researchers and practitioners. In this approach, the farmer had an active a role to play in setting the agenda during planning and implementation activities.

Several efforts have been made in Ethiopia to bridge the research-practice gap through the introduction of new technologies [74]. However, in a situation where there are different levels of participation and the farmers are at the receiving end, whereas the researchers and extension professional are controlling resources for technology implementation, it is not easy to eliminate such a gap $[74,75]$. With such type of relationship, the farmers believe that, whenever these technologies are introduced, their participation is limited to following and adhering to instructions provided [75]. Under such circumstances, farmers' trust is low whenever new initiatives are introduced by the people whom they believe to have a hidden agenda or acting on behalf "state authorities or other agencies". However, in a situation where there are efforts to build trust in a democratic atmosphere, this is empowerment; the farmers are able to take new technologies with the seriousness they deserve. For example, the sustainability of the PPT is not only dependent on its effective performance in the control of stemborer pests, but also on market forces from the demand and supply of Desmodium and Brachiaria seeds and other inputs. In addition, it is dependent on leadership initiatives from the micro level, i.e., at the household level where the head ensures that all members of the household participate and their capacities are built with the PPT-based knowledge. The farmers can organize and allocate their farm families in terms of roles and responsibilities on carrying out the PPT activities. The PPT was implemented as an enterprise where the different family members were empowered to exploit the various benefits and opportunities which come with it, e.g., from Desmodium and Brachiaria seed production, process and marketing as a source of income generation of livestock fodder for milk production. This was also in anticipation that one of the family members is incapacitated or moves on to other activities, and the rest of the family members can continue with the technology implementation. This sort of leadership at family level was built from the confidence derived by the farmers, whereby their role is recognized by both research and extension professionals. The farmers' leadership was demonstrated by their ability to initiate, conduct experiments and take decisions with confidence regarding the PPT implementation activities. For example, researchers recommend the establishment of the PPT using line planting where the seeds are sown in holes or drills using a straight line. However, the farmers preferred to use ox-drawn ploughs to drill the lines (Figure 4). These lines were not straight as required or recommended by the research or extension, but the farmers, thriving in a participatory and democratic learning process, could make decisions based on valid reasons on what they knew works best for them. This was different from previous relationships where they were dictated by the Development Agents (DAs) or local administration and researchers on what to do during on-farm trials or implementation of new technologies. This time, they could use their own measurements and tools:

The joint implementation of the PPT enhances participatory leadership in its approach whereby it enables everybody from farmers to researchers to participate in the technology. Thus, enabling all the participants (i.e., stakeholders) to develop and contribute skills to manage its implementation and also push the research agenda ... Through this approach new players are attracted into the research process and contribute to good results, e.g., the private sector, youths and women .... all the players involved are able to learn new skills on PPT openly from each other and by drawing on own experiences. (Researcher, April 2015, EIAR, Bako center) 


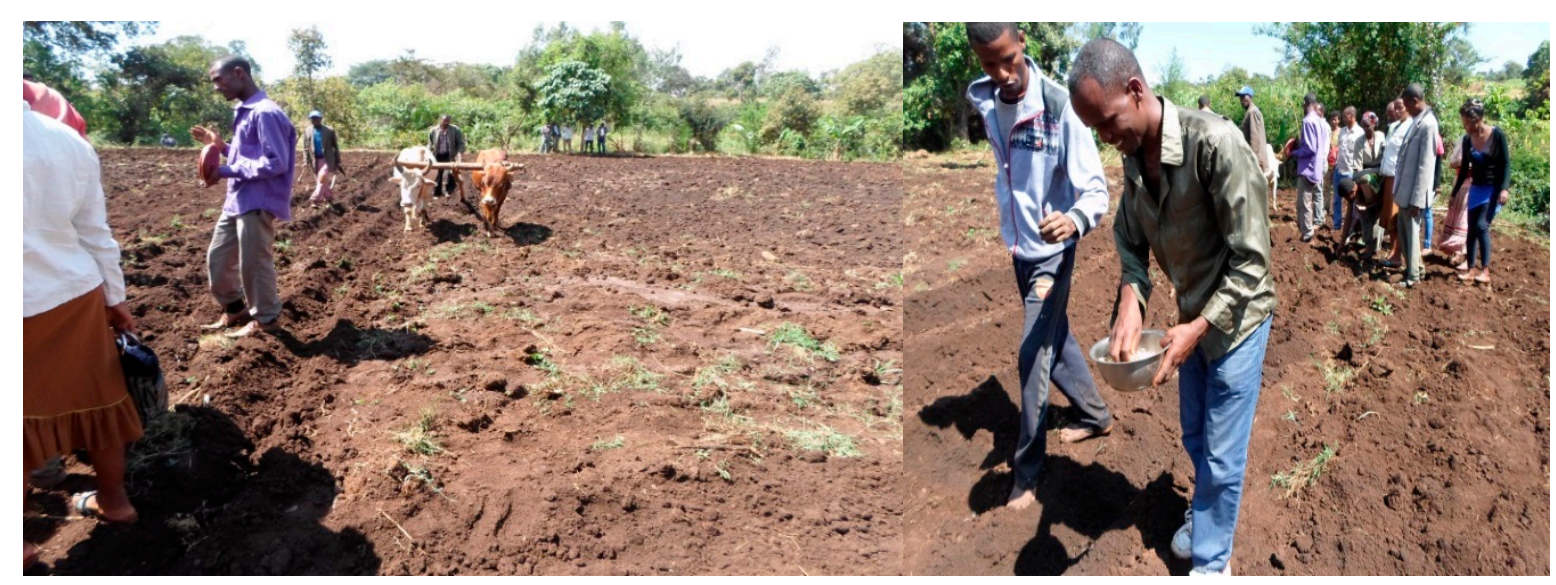

Figure 4. Pictures of farmers, extension officers and researchers' joint sessions of establishing the PPT.

The effort to change research and extension services provision is in line to what was recommended by Deneke and Gulti [74], i.e., linear relation should be replaced by systems which are iterative, interlinked and overlapping where by the role of the farmers is not that of recipients of technologies developed elsewhere but to empower them to have confidence and trust to contribute to decision making together with other stakeholders. The stakeholder collaboration process was organized in such a way that the on-farm implementation process was undertaken in a participatory manner by the team consisting of the farmers, the Development Agents (DAs), Woreda/District level extension professionals and researchers. The on-farm PPT activities created a platform for these stakeholder groups to interact and learn various topics related to stemborer pest control, soil and water conservation and fodder production. Such a joint working relationship was an opportunity for each stakeholder to introduce and contribute skills on the management and implementation of the PPT and other related emergent enterprises or benefits:

The DAs, researchers, visitors from overseas, Germany and Kenya, have been with us from the start to date ... Team work always has positive outcomes ... . The team has been around from sensitization, training, planning for all the implementation stages to now ... This has formed a continuous interaction process for learning and appreciating the efforts of each other. (DA, Bako Tibe, March 2014)

The farmers were confident with the promoters of the technology. This was based on the reputation of the PPT which they heard; it has been researched vastly and there were many experiences to draw from other countries in the eastern African region such as Kenya, Uganda and Tanzania. They share similar circumstances with farmers from these countries who are also faced by the same stemborer challenges. They were flexible and at ease to make decisions about the PPT from the beginning. In their own circumstances as Ethiopian farmers, 2-3 cropping seasons with the PPT was sufficient to enable them to have their own concrete experiences. At the time, they were optimistic:

icipe Director General is Ethiopian and she is supporting this technology ... . She is fully aware of its benefits, so we shall fully embrace it and make it a model. What she thought for her country and population to come out of poverty and challenge of being faced with pests, erosion, and fodder. We are receiving this information through the extension and researchers at the local level. (The PPT farmer, Bako Tibe, April 2014)

In addition to cereal crops, farmers plant horticultural crops for household consumption and for the local market as a source of cash income. These crops are affected by similar pest problems such as nematodes, armyworms, aphids. etc. Out of curiosity to find a solution to the horticultural pest problems as well, a farmer raised a question whether Desmodium could help in addressing the problems he has with tomatoes and cabbages on his farm. This was an interesting question for the 
researchers and extension alike. The farmer took the initiative to learn about it. This was based on what he observed for the first time, i.e., the maize crops had less infestation with stemborer pests when compared to the previous maize cropping seasons. Contrary to the conventional wisdom of waiting for an answer from the specialists, he offered to run the trial experimentation by growing tomatoes on $25 \mathrm{~m}$ by $25 \mathrm{~m}$ plot intercropped with Desmodium. Out of this plot, he planned to keep records on the observations made and he was willing to share with researchers and extension staff his own findings. Such a bold gesture from the farmer was attributed to confidence and freeness gained from the joint nature of interaction with researchers and the extension staff. This also was a boost to the other farmers to believe that their ideas and simple experiments can contribute to generating new knowledge in a research engagement process. Such a research initiative is an example of how through the empowerment and supporting farmers' ideas can contribute to generation of new knowledge in pest control. The farmers experimentation, combined with the laboratory-based methods, can potentially reduce the time usually needed to generate results to address the immediate need or real-life problems.

Weeds compete with the maize crops for nutrients and moisture. It is assumed that the farmers should weed their maize even when the crops have matured. However, the farmers had a different perspective. At the later stages of maize growth when they start flowering or forming grains, the farmers stopped weeding. From their point of view, the weeds together with maize stalk leftovers was fodder for their livestock after harvesting the maize cobs. At the same time, weeds retain soil moisture due to sufficient soil cover. With the introduction of the PPT, some farmers in the area saw similarity with weed retention on-farm. They were able to connect with what they already knew and what the PPT had in store for them. Instead of previously leaving weeds to grow with their crops, introducing Desmodium as a companion crop seemed a novel idea. It addresses the stemborer problem and provides additional fodder for livestock. This helped to dispel the rumors which were initially spreading in the study areas that Desmodium was a weed being introduced by researchers and extension staff:

The overgrown weeds are fodder for livestock. Immediately after the harvest of maize, animals are left to freely roam and feed on "weeds" plus the maize stovers.... Now with PPT, Desmodium does the same. Besides, it is a perennial crop which can be cut back and fed to livestock. It is a permanent source of fodder ... this is good. (the PPT farmer, during FGD interviews, March 2014)

\subsubsection{Farmers Leadership in Push-Pull Technology and Related Activities}

A few farmers managed to overcome the negatively rumored messages. These are a group of farmers who went ahead to implement the PPT despite these rumors. They eventually became the lead farmers and as leaders to their community through sharing and extending information to fellow farmers during events such as field days and face to face encounters with fellow farmers leaders [76,77] while at the same time playing a key role as key stakeholders in the research process. They embraced the leadership role for fellow farmers to emulate $[78,79]$. They were able to make decisions regarding the PPT based on their own intuition and experiences on what they think is of best interest to their community. This statement was echoed by the Ministry of Agriculture extension expert:

The PPT has become like a "school feed", produces a lot of knowledge, food to feed us humans and livestock... most farmers resist new technologies, but the model farmers accepted to lead the implementation of the PPT for the first time .... Other farmers from other Woredas will learn from their example by attending such field days' events which is an important platform for learning and experience sharing. (Extension expert, Bako Tibet, during the PPT farmers' field day Sedan Kite Kebele, March 2014)

The PPT learning plots were established and placed under the management of the lead farmers. This gave them an opportunity to experience the first-hand gains of the PPT on their farms 
and knowledge about the technology as compared to fellow farmers who were visiting to learn. The day-to-day interaction with research and extension experts, new farmers and inquiries, elevated their quest to search and learn more information about the technology. This increased their level of expertise, not only on PPT, but other management skills such as decision-making and communication skills from their greater contacts beyond their immediate surroundings [78]. Their contact with other stakeholders such as the researchers and extension personnel during the planning and implementation, monitoring and evaluation of the PPT activities, visitors from other countries was a learning journey for them. The information and new knowledge gained by these farmers was to be freely shared with their fellow farmers through social events such as community meetings, market places and even churches. Their social standing in the community through undertaking such new initiatives was elevated. This is an indication that all the farmers are potential innovators from the beginning if they get the chance to take an active role to participate in learning and implementing new initiatives. To be able to illustrate this aspect in detail, here is an example of one of the PPT host farmer.

The PPT host farmer Kebele A is an illustration contrary to what is commonly thought, that lead farmers should be well established with good social standing and well to do in the society in terms of assets and landed property or formally educated. However, this particular case is a farmer aged about 38 years without formal education, no family and land of his own. He lives with his elder brother's family and among other extended family members. He takes care of his extended family's large herd of livestock of over 30 animals consisting of dairy cattle, oxen, sheep, goats and donkeys. He rented the land from his brother to plant maize and accepted to participate in the implementation of the PPT. He is the most active member of the family even though he has no family of his own. From his active farming and other social activities, he is respected by the community members. He was selected for participation based on his interests as the farmer to take up new initiatives and the respect he had earned himself from fellow farmers in the village.

Innovative/model farmer is the one who is ready to accept, learn lessons, pass lessons to other farmers, conduct own research and share with fellow farmers and researchers how technology works on reducing the losses due to stemborers pests. (Small scale irrigation and drainage expert, Bako Tibe, April 2015)

During further discussion with the irrigation expert, he had the same farmer in mind, from Kebele A; he commented that the respective farmer was always willing to offer his rented farm for the trial of new technologies. He is a lead farmer and risk taker and previously had participated in the establishment of trial plots of other new technologies such as tree nursery for agroforestry and Napier grass nursey for fodder production in his community. PPT is among these initiatives he is keen to try and bring to fruition by working closely with the researchers and extension staff. "Apart from the immediate benefits such fodder, reduced pest infestations and soil conservation properties, PPT is a promising technology" the farmer commented. "He is fully in it and looking forward into the future on what the technology has to offer to him", commented a fellow farmer in the community.

The technology is interesting for farmers, researchers and student learning. It addresses the complex challenge of stemborers simply $(\ldots)$ and has attracted many schoolchildren from around the village who are interested to learn how the PPT mechanism works in controlling pests in such a simple way. This is science-simplified and in the hands of farmers. This is because I am able to talk about science-based practice and practically implementing it in my own farm. (Interview with PPT farmer, Bako Tibe, March 2015)

This particular farmer was able to talk easily and with confidence about the new PPT because he had understood how it works and it was practically existing and implemented on his farm. He took it upon himself to become a leader in information sharing with fellow farmers and school going students who had interest in learning the technology. The "teaching" aspect is what motivated and made him pay attention during interaction with researchers and extension staff to learn in great detail and later to 
respond with accurate information to questions raised by those seeking to know more about the PPT. Combining his own intuition with local knowledge and understanding of crop-pests interactions and practical observations, he was able to talk about the PPT freely and easily. This, according to him, was indeed science demystified [59] and gave him an opportunity to become a leader. Apart from stemborer challenges, he was motivated to participate in the PPT to address other problems of soil erosion and mono-cropping. These practices contribute to soil fertility losses in the area and the PPT was seen as a novel idea which was fitting and has the potential to address these challenges. The majority of fellow farmers have no experience or knowledge on cereal crops intercropping practices and are dependent on cereal-livestock production systems. They are constrained by perennial fodder shortages. To these farmers, the PPT was an opportunity to learn and share wide ranging knowledge and practices.

Apart from pest control, food and fodder production to environmental conservation, the PPT is easy to understand and use despite the underlying scientific principles at play. The resource-constrained farmers are not able to afford expensive farming inputs aimed at increasing productivity such as fertilizers and pesticides. (Interview the PPT farmer, Bako Tibe, March 2015)

Another example is a farmer, from the neighboring village B who had actively participated as lead farmer in other technologies previously introduced in the village, thus his social standing was already elevated. Whenever new opportunities arose, he still stands out to be selected by fellow farmers and the local administration as their farmer leader.

I have participated in other extension packages such as tomato, onion, and maize production. I am ready to make the PPT a model and aesthetic farm in my village. I previously learned from Sasakwa Global2000 farm extension model plot, so am determined. I have become a lead farmer through training and actively trying extension packages. Previously I was selected by the Kebele administrator as a model farmer in the village. I am happy with being model farmer, it is rewarding from the certificates of participation and sense of satisfaction either socially or economically.... . I have managed to invest in a new house, bought a mule and cart from increased farming income from being a model farmer. (Interview with the PPT farmer, Bako Tibe, March 2015)

The selection of farmer leaders was undertaken by the other farmers who had trust, confidence and were comfortable to have one of their own to take lead and whom they could learn from. Their elevated social status after participation in new technologies was a motivating factor for other farmers with similar backgrounds to emulate. Although it may seem to be pointing to replicating the "farmer opinion leadership" where an individual farmer is believed to influence other farmers' attitude and opinion [78], farmer participation in the PPT was different. It involved participation of other stakeholders (academic and non-academic researchers) in sharing of their diverse forms of practices, expertise and knowledge on stemborer pest control and their input and contribution to the research process was a result of joint efforts.

\subsection{The Challenges}

\subsubsection{The Spread of Negative Rumors Regarding Push-Pull Technology}

The concept of intercropping Desmodium with maize as an effective cover crop was not as well received as one would have expected. Some of the farmers were reluctant to embrace the PPT either due to cultural orientation or personal attributes such as fears, not trusting new information or technologies or being swayed by negatively rumored information. For example, in Yayu Woreda, some farmers were thinking that Desmodium was weed and wild plants being introduced into their farms to become an unnecessary competition with food crops or to be just a nuisance. According to some of these farmers, Desmodium was annoying. It gets stuck on clothes when walking through or weeding 
their maize fields. Some of them knew Desmodium as a wild plant growing on the farm hedges or in the forest and could not comprehend the fact that it can be intercropped with maize. At the same time, freely roaming grazing livestock after harvesting of maize is a common practice in the study area. Therefore, to some of the farmers, researchers and extension professionals, the introduction of PPT was not likely to work. In particular, they had doubts on how the PPT could be managed during the off-season when there is no growing of maize. That means, the perennial PPT companion crops will be destroyed and would need to replanted during the subsequent seasons. However, such doubts were expected because the PPT was being introduced into the area for the first time. To the promoters of the technology, the emergence of negative rumors and misinformation are some of the key areas of concern which had to be understood and addressed. These issues turned out to be the key learning points or resources for detailed learning about the technology [79].

I had many questions in my mind on the future and sustainability of this technology. Now slowly the questions are being answered (... ) such as roaming of livestock immediately after harvesting maize, preparing land for planting maize in the next season in the presence of Desmodium and Brachiaria grass ( ... ). Because of the interactions we have had together with other stakeholders over time, I have cleared some of my doubts. (PPT Follower farmer, FGD in Bako area, March 2014)

\subsubsection{Emergence of New Conflicts as a Result of the Push-pull Technology Implementation}

The introduction and implementation of the PPT in the study area had mixed blessings. It not only brought new knowledge on managing stemborers and other benefits, but also new dimensions of conflicts which were not expected nor existed before.

Initially we had an informal agreement on water use and allocation mainly for irrigation purposes. Now with the introduction of the PPT, some farmers who didn't understand the technology started questioning why water was diverted to these plots ... This caused us to have irrigation water use conflicts, forcing us to irrigate PPT plots at night with the aid of torch. (Interview with the PPT Farmer, sedan kite Kebele, Bako Tibe, March 2015)

The implementation of the PPT in the area had contributed to the emergence of water use conflicts which had not been experienced before. The conflict was as a result of using irrigation water in the PPT plots as a supplement to low rainfalls in the area during the period of the study. The result may be seen as a negative outcome, but it brought the problem to the attention of the Ministry of Water and Irrigation for an intervention. Previously, water use agreements in the area were informally set up among the farmers who were practicing horticultural farming and other users along the Gibbe River. However, with the introduction of the PPT, it generated mixed reactions on water use allocation which was in high demand from many users along the river. According to the horticultural farmers and other users, there was no water allocation for the PPT. That means the allocation was causing unnecessary demand on the already "scarce resource". Despite the allegations, the PPT farmers attributed these conflicts to jealousy from their fellow farmers. This was because the maize crops in the PPT farms were outperforming the horticultural crops in terms of productivity and market value prospects. Previously, without the PPT, these farmers were planting maize using the same water and such conflicts were not witnessed. To prevent the resultant conflict from escalating or recurring in the future, the officials from the Ministry of Water and Irrigation who were part of the research team, together with other stakeholders, convened a joint meeting and agreed to have a formalized water use arrangement. This was a bottom up approach of formalization through stakeholder mobilization and engagement. The agreements were put on paper with a clear outline on who, when, where and what amount of water is allowed to be used for irrigation along the river considering other users downstream on the Gibbe River, which cuts across many Woredas in the region. This is in concurrence with Gray [18], whereby the absence of conflict resolution is a detriment to any form of transdisciplinary collaboration which requires integrating of diverse aims and interests among the stakeholders. In such circumstances, 
leadership with process skills to manage and facilitate conflict resolution plays an important role towards the success or failure of transdisciplinary efforts [18,30].

"My wife was skeptical and lost interest in the technology. She felt that I have been misled and sold out the land without her knowledge," the lead farmer commented. To this particular farmer's wife, this appeared as a sort of land grabbing where she could lose access to her land on which she previously could grow crops-and choose them freely on an annual basis-for her family's livelihood. Land is an important resource in terms of investment and food production opportunities for the socio-economic and environmental wellbeing of the smallholder farmers. Thus, when the same land is targeted to be acquired by outsiders who are either individuals or companies to serve their interests at the expense of its farmers, it can be seen as a form of land grabbing. The introduction of the PPT can be easily be equated with "land grabbing" which take place through introduction of commodity crops such as sugar cane, tea, coffee, Jatropha, etc. by multinational companies. This is because the crops are perennial, i.e., they are planted once and remain on the farm over the years. In most instances, the owners of these lands are poorly informed of the consequences of the investments and growing certain crops on their farms. There are several advantages highlighted by the proponents of such land transactions, e.g., food production, technology transfer, job creation and infrastructure development in those areas. They argue that such investments on land will enhance yield and close productivity gaps through the supply of high capital agricultural inputs such as irrigation and other technologies [80]. With awareness creation and information availability either through media or civil society groups, the farmers are seemingly alarmed with new technologies which are tailored or based on land investments. The PPT was linked with such examples. It was introduced as a new technology with perennial companion crops planted under smallholder farming systems. At the same time, it was being promoted by researchers from other countries.

\subsubsection{Inconsistence of the Push-pull Technology with Locally Established and Traditional} Farming Practices

The joint implementation of the PPT by researchers and other stakeholders was linked with introduction of new information which was inconsistent with their common practices, thus creating an uncomfortable psychological state due to uncertainty from what the technology had in store for them and famers were not sure about that. It was seen as source of conflicts by challenging the locally entrenched practices by the farmers and to even the extension and research officials. For example, maize is grown as a mono crop. Intercropping maize with an additional crop was not a common practice among the farmers. The agricultural extension staff had no experience on how to go about changing this practice. That means, introducing the PPT was directly conflicting with this already entrenched and established culture of mono-cropping. At the same time the farmers and extension officials were accustomed to the culture of conventional and linear technology transfer as the main source of extension messages. The participatory processes of stakeholder planning and implementing activities on a joint basis was seen by these officials as a source of conflict to their "usual business environment and ways of doing things". The farmers are usually relegated to the receiving end and they are only supposed to implement what have been instructed by the extension or by researchers. The off-season Brachiaria and Desmodium crops management introduced by the PPT required that the farmers had to fence off their farms or guard their farms from freely roaming livestock, which was conflicting with the age-old traditional practice of allowing livestock to freely graze.

However, this can be overcome by planning and working together by combining different ways of knowing, doing and learning among different social actors [10]. This stems from the fact that such differences as technical competencies, cultural beliefs, social status in the community and language barriers may contribute to a mistaken understanding and meaning, thereby leading to distorted or even unheeded messages [81]. Therefore, effective communication and coordination between such individuals can be used to overcome cognitive dissonance [82]. It is also specified that the PPT activities should last at least $2-3$ maize cropping seasons for effective performance and learning 
to take place [51]. This gives sufficient time and allows stakeholders involved to become familiar with each other and adjust their local practices and beliefs to new technology and even the ways of working. This means that the organization and leadership of the TD research process provides the direction towards successful interaction, fruitful collaboration and learning. With the notable example of Ethiopia, the organization and implementation of the PPT requires institutional changes such as embracing participation by both non-traditional players such as private sector actors and youthful farmers who are showing interest in commercial or enterprise-based farming activities. This will broaden their collective learning beyond traditional communities and approaches of academic researchers and state-run extension agencies. This view was echoed by the key informant:

What we have learned so far never existed before on intercropping cereals with Desmodium ... The PPT implementation process brings on board other new players such as the farm input sellers, youths and women to contribute to agriculture ... During dry season, farmers plant tomatoes, onions and cabbage as horticultural crops using furrow irrigation. This is a new custom of planting maize with Desmodium and Brachiaria grass during dry time. (Ministry of Agriculture extension expert, Bako Tibe, April 2015)

The emergence of conflicts as a result of new ideas from the PPT, became embraced and used as an opportunity for in-depth learning about the technology and also to find solutions and their possible adaptation. According to Suchman [83], these kind of situations require boundary crossing and indeed effective leadership to manage the transitions. During discussions on the sort of leadership required among the stakeholder teams that will enable the successful learning of PPT despite situations where it is seen as a potential source of conflicts with local practices, it was suggested that:

There is need for flexibility among the collaborative stakeholders. The actors have to understand the needs of each other, their potential strengths and capacities. Although understanding the needs of the people and working on their minds is challenging ... . but, the leaders should be experts who are committed with a guided vision long into the future. (Agriculture extension expert, Bako Tibe Woreda, April, 2015)

\subsubsection{Lack of Formal Stakeholders' Memorandum of Understanding}

There was no formal Memorandum of Understanding (MOU) among the stakeholders with details on collaborative working arrangements between the researchers and extension staffs from the different ministries and departments. The working arrangements were based on individual commitments by the staffs from the different departments and ministries. However, between partner organizations, it was not always smooth running. For example, some of the research and extension staff were asking for payments to participate. They were seeing the PPT implementation not as part of their mandate or their acknowledgement was unspecified. Some of the extension personnel and researchers felt that participating in the PPT implementation was conflicting with their day-to-day activities unless it was formally arranged. The MOU concerns were necessitated by the fact that previous initiatives on joint stakeholder engagements had not yielded tangible results but were limited to boardroom agreements. For example, the Agricultural Development Partners' Linkages Advisory Council (ADPLAC) was meant to strengthen linkages among researchers, extension staff and farmers. However, this had not been generally operationalized due to challenges from lack of actor commitment, financial limitations, staff time to frequent transfers turn overs. Therefore, it was hoped that collaboration cemented with a MOU in the implementation PPT activities with specific stakeholders could be a better way to learn how to deal with this kind of challenges.

\section{Discussion}

The implementation of PPT is associated with stemborer pests control, Striga seed bank depletion in the soil and/or the provision of fodder for livestock. This is based on the immediate results or the products farmers experience or benefit from practicing the PPT. However, beyond these benefits, 
there is a challenge on its sustainability. Apart from the durability and effective performance of the companion cropping, the sustainability of the PPT as an innovation is dependent on the strength of relationships and social learning processes which occur among the collaborating stakeholders, type and nature of new enterprises and activities which emerge or are created during its implementation. Equally, the sustainability depends on whether these activities will continue being implemented or practiced by the farmers over the successive cropping seasons.

\subsection{Opportunities for Interactions}

The Transdisciplinary action research approach and the practical on-farm nature of the PPT implementation provided frequent interactions and continuous learning based on its workings and even challenges for both researchers and farmers stakeholders. This was evidenced by their comments:

The PPT is a unique technology. I think it is sustainable based on its integrated nature, and continuous learning on step by step basis ( ... ) There are many questions which can be raised and answered with the introduction of the PPT on the farm. The major one being, it is addressing the serious challenge of stemborer pests in maize production $(\ldots)$, we can have the best breeder seed, best fertilizer, enough rainfall and well-prepared field, but without a sustainable, affordable pest control, still maize productivity will be affected or reduced. You may have all the capital, but if no effective pest control, you still have low crop yields. In the future, this technology has lots of potentials. (Interview with the Ethiopian Institute of Agricultural Researcher (EIAR) April 2015)

The PPT is a useful technology for the new generation of farmers. This is because it lasts longer in the field and provides opportunities for continuous learning and interaction [ ... ] and the farmers have started to understand how environmental factors contribute to pest problems and how the same can be used on their management. (Interview with the PPT farmer, Bako Tibe, March 2015)

"I had many questions in my mind on the sustainability of this technology. Now, slowly, the questions are being answered" a follower farmer commented during FGD. Farmers like to participate in new technologies which can give them flexibility to improve in their farming enterprises or maximum returns on their investments. For example, the minimum average plot size recommended for PPT is about $600 \mathrm{~m}^{2}$. In the study area, due to population increase, the land is scarce, and most farmers own less than 2 ha of land. The PPT plots require management practices which farmers can acquire with time, and when convinced with the performance results, they can expand to the entire farm or if not convinced, they can drop the technology. This makes the practice of PPT a learning journey. The benefits, such as fodder and stemborer control, are witnessed from two or more maize cropping seasons [51]. This requires patience to get full benefits and even to make the adoption and adaptation decisions. During the interaction process among the stakeholders, the PPT provided opportunities for learning about other farming methods and related enterprises, e.g., farmers were able to learn how to plant maize under irrigation. In the past, farmers in the study area have been growing horticultural crops using irrigation. With irrigation the PPT farmers were able to produce maize for food and additional fodder for their livestock. During the dry season, most farmers do not participate in cereal crop farming and let their livestock roam freely scavenging for scant fodder in the harvested fields. This not only affects the production levels of the livestock, but also contributes to environmental degradation through overgrazing and destruction of vegetational cover. The PPT had shown the potential that these negative environmental conditions can be addressed and even reversed:

Land for grazing is reducing and slowly in-door feeding is gaining currency in the district. Ethiopia has highest number of cattle in the region, but the quality and productivity is poor due to low quality feeding. Therefore, the PPT is part of the solution in terms of complementary fodder production for livestock in the area. (Interview, Ministry of Agriculture, livestock production expert, Bako Tibe, April 2015) 
The application of PPT as a method for stemborer pest control had not been used previously by the MOA officials in the study area. Despite this, as decision makers, their commitment and policy support were needed from grassroot to national levels of administration. The commitment shown from farmers on learning and their willingness to use the PPT was an encouragement for the officials to provide the necessary support. This is what culminated in the inclusion of the PPT as part of MOA's extension and soil and water conservation programs. The PPT was included as part of the Ministry's Integrated Pest Management (IPM) program and also in the soil and water conservation measures. This was because it was complementing the already existing efforts. For example, the MOA officials encouraged farmers to plant Brachiaria grass along the farm borders and slopes and intercropping maize with Desmodium to reduce surface water run-off and prevent soil erosion. In the past, the same program promoted the use of vetiver grass as a cover crop; however, due to the turf nature of its leaves, it is not preferred for harvesting as fodder for livestock. Brachiaria grass was preferred to vetiver grass, which has same growth and conservation properties, but the soft leaves make it easy for feeding livestock.

The soil and water conservation such as terracing, planting grasses on the hillsides or planting trees are conducted as mass campaigns mainly with long term objectives. In contrast, the PPT was done based on personalized contact with individual farmers and the conservation benefits have both immediate and long-term returns, e.g., Brachiaria grass providing fodder and stabilizing the soil on the hillsides. Even though the technology was proven as a potential platform upon which both immediate and long-term farming enterprises could be built, the question on its sustainability was still lingering in the minds of the stakeholders' team. To address the sustainability concerns, the team raised and discussed, among other issues, the potential linkages with new market opportunities as well as the PPT as content for training agriculture students in the technical and vocational centers.

\subsection{Promoting Push-pull Technology Based New Market Opportunities}

The implementation of the PPT came with new market opportunities for the farmers and other stakeholders to participate, i.e., in commercially-oriented farming. Some of these farming enterprises include dairy, beef (fattening), commercial seed production and agro-dealership for the PPT inputs (such as Desmodium and Brachiaria seed material). The coming together of several actors creates a market place, a network of the PPT practitioners with a broad-based social capital to draw from as well as for learning and dissemination of the PPT. As a learning platform, the PPT can be used to promote other technologies which have a linkage to it. For example, during the off season, the PPT plots had sufficient soil and residual moisture which farmers used to grow chickpeas. The high demand and good market prices for chickpeas in Addis Ababa and other big cities was a strong incentive for other farmers to participate in the PPT. This was because, during the dry season, only the PPT farms in the area had some residual moisture due to soil cover provided by Desmodium. This was an incentive:

For the sustainability of this technology, we need to supply seeds for planting and target young farmers and develop local structures on seed supply ...... The PPT is setting up the pace for accepting other new technologies. We have to use the existing platforms for us to get maximum benefits and, for its sustainability, we have to ensure seed source from own production. (Interview, Women and youth affair affairs expert, Bako Tibe, April 2014)

Sufficient production and distribution of Desmodium and Brachiaria seeds forms the basic component for sustainable expansion of the technology. The involvement of farmers in the PPT seed collection and production is a very important practice towards achieving this goal. This can only be achieved if the farmers and traders will have the interest to invest in seed production and distribution.

Bako research center has no mandate to produce and sell the Desmodium seeds; we are only engaged in conducting research and producing breeder seeds. However, we can provide leadership on the distribution of the produced seed, i.e., support seed production and 
coordinate the distribution, but the government authorities should provide guidelines on production and distribution. (Interview, EIAR researcher Bako center, November 2014)

Farmers in the area know Desmodium as new crop which came from the research centers, it is not an indigenous crop. It was introduced as a fodder and cover crop for livestock and in coffee farms. Farmers at the same time had no knowledge on seed production, processing and selling as a source of income. This is an opportunity for learning and to meet the demands of the new and emerging Desmodium seed market. (Interview, EIAR researcher Matuu Center, March 2014)

There is significant production potential for silver leaf and a modest quantity for green leaf Desmodium from the Yayu and Jimma areas adjoining forests and along the farm hedges. This is an opportunity for the youths and women farmer groups to participate in the PPT through Desmodium seed collection as a response to the demand and market for supplying the seeds for the new PPT farmers in the country. For instance, 3 tones of Desmodium seeds were bought by icipe in March/April 2015 from the farmers, Metu and Jimma Research Centers, and agro-dealers in Jimma. This was a good incentive for the producers to collect more seeds and an opportunity to generate cash income for the farmers. The market linkage was associated as a measure for sustainability of PPT. The private agro-dealers have an existing network of seed collection and distribution and Desmodium is one of the seeds collected and traded. The successful promotion and expansion of PPT will increase their market penetration with Desmodium seeds and this has significant influence on the sustainability of the PPT.

\subsection{Applying the Push-Pull Technology Knowledge as Training Content}

The PPT content is suitable as a curriculum material not only for training farmers, but also for training agricultural college students who are training to become DAs. The DAs training takes two years and are posted in the village levels as agricultural extension officers. Their participation with tutors during farmers' field days was an opportunity for them to link theory with practical realities on the farmers' fields. This stimulated their interest to learn more with the intention to apply the knowledge when they graduate. They learned that the PPT touches on key sectors of their training: crops, livestock and natural resources management. This was noted by one of the students who participated during the farmers' field days:

The PPT is simple to implement, it is cheap, uses less expensive inputs, it is very important for the livelihood of the farmers. Bako College is a center of excellence for training DAs in plant science and animal health. Including the PPT in our curriculum will be an opportunity for information transfer to the students who will finally become Das ... . and will transfer the same knowledge to our farmers. (Interview, student Bako College, April 2015)

Bako technical and vocational training college is mandated to train frontline extension staffs, who are otherwise called DAs. They are employed immediately after graduating to work as village extension staff. During an interview with one of the tutors who attended farmers' field days, he said:

In our college, we provide DA's training in two types. That is occupation-based and project-based. The former one is based on Ethiopian occupational standard prepared by Ministry of Education. For the second one, the projects are prepared based on the competencies or topics selected from list of occupations like crop production, animal production and natural resource conservation. The project-based training contains competence, entrepreneurship and technology. So, having our curriculum content with technologies like the PPT is important for our students who will eventually teach farmers. (Interview, Bako college tutor, April 2015)

This statement was backed up by another tutor from the college: 
The PPT field day provides an opportunity for the teachers to learn and have experience with the new technology. Now with practical knowledge, it is easy to read and understand and transfer to learners who will become Das .... This is a perfect opportunity for introducing the technology as a tool for training and for learning by various disciplines .... and seems to touch all the departments ... from technology, trade, crops to livestock/health etc. (Comment by Bako college tutor during farmers' field day, April 2015)

\subsection{Mutual Trust in Transdisciplinary Stakeholder Interaction}

The critical basis for stakeholder collaboration and cooperation is trust which is built and maintained through regular meetings, openness, transparency and offering something of immediate importance to the stakeholders [58]. The PPT implementation process follows the maize crop phenology and covering several cropping seasons. The stakeholder interaction during these seasons has the potential to generate mutual relationship and agreements among the stakeholders involved. Sometimes, it can also lead to disagreements. In normal situations, for such interactions to come to a point of developing trust requires some time and sustained interactions [84]. During the PPT implementation over successive seasons, the stakeholders have an opportunity to frequently interact and learn over common and emerging issues related not only to stemborer pest control and other farming enterprises, but also to form strong relationships among the stakeholders.

Individual stakeholders must know each other well enough to be able to interact productively [83]. They must trust each other and also have no doubt on their willingness to contribute to the common enterprises of their community. This makes them feel comfortable to openly discuss and speak truthfully to each other in an attempt to address their common challenges. In Ethiopia, for example, as an outsider, the first author observed that there is a culture of benevolent trust among the people, especially in the rural areas. This means that nobody is willing to share information which can lead to some harm on a neighbor. They may prefer to keep useful information rather than share what is injurious to their neighbors. This culture makes them share information on new technologies or opportunities which are meant to directly address their real-life challenges now and in the future. Achieving the expected increase in maize production by $4-5 t /$ ha and provision of high quality livestock fodder which are associated with introduction of the PPT, is an incentive of immediate benefit for the farmers and other stakeholders to develop interest and share information regarding the technology. However, at the same time, if these farmers do not trust the source of information, they could easily give up on its benefits. The trust is even higher if the information comes from a competent source, i.e., the farmers know that the person is knowledgeable about a given subject. Such a culture of appreciating new information from competent sources and sharing it freely is an entry process to the learning journey. "Farmers easily trust new technologies if it is from competent contacts or sources in the community such as lead farmers, extension staff and researchers whom it is assumed have already tested or put into use before introducing or recommending it to us" commented a PPT follower farmer during an FGD. There may be histories of mistrust, personal differences or communication barriers between farmers, researcher and extension services providers in the past [31]. However, the TDR approach and the need to address common challenges of stemborer pests contributed to some extent to improved ties between the different stakeholders to learn and implement PPT together [85]

Therefore, the researchers, extension staff and smallholder farmers started to work together from the point of trusting each other's contributions. Although building such trust requires time which is longer than the time taken in this study, some "sort of ties" in an evolving learning journey of the PPT implementation was initiated:

I learnt that the Ethiopian farmers are interested to take up and adopt the PPT more than Kenyan and Ugandan farmers. It will take a short time to achieve the high adoption numbers due to the fact that we trust new information from competent sources so long as it addresses the problem at hand. (Comment by follower farmer who participated in exchange visit to Kenya and Uganda, FGD, May 2015) 
This observation was based on the fact that, the PPT technology has been promoted in Kenya and Uganda for longer time than in Ethiopia. The reasons cited for low adoption rate was related to the commitments by the research and extension systems of these countries which had not taken up the technology at policy levels and promotion being mainly research driven. The Ethiopian MOA officials requested for the introduction of the PPT into the country from the icipe researchers with the support of donors in the year 2012. This signifies the high level of trust the MOA officials have on research and also their commitment for new information to address the problem of stemborers. However, this dependence on research and extension officers as the main source of information and knowledge on new technologies is not sustainable in the long-run. For example, every year, the government sets aside 30 days dedicated for soil and water conservation efforts. The farmers are compelled to participate in digging terraces, and planting soil cover crops such as vetiver grasses on the slope areas. In most instances, this has degenerated to mistrusts, whereby the farmers do not trust the intention of the government officials, whether from research centers or extension services. This is also linked to some of the cases where the DAs are used to collect "taxes" on behalf of the government. The farmers are forced to cooperate with the political power needs. This is completely conflicting with agricultural extension activities where farmers are supposed to be treated with freedom and trusting by the extension agents.

Farmers often have some apprehension vis-à-vis new technologies whenever introduced in their localities. Connecting with the previous experiences during the SG2000 technology promotion, the farmers were not sure what the PPT had in store for them. This was attributed partly to the lack of enough information at the initial stages of implementation. However, through continuous interactions with researchers and extension personnel, they were slowly appreciating the technology and learning in detail how it functions. For example, the farmers had noticed that with their current maize crop, the perennial pest problem of stemborer and birds had decreased:

I haven't seen stemborer attack this time round in my maize field .... This is contrary to during the normal cropping season, the stemborer always infest stems and birds always attack the maize tassel ... . I think birds are searching for stemborer eggs on the maize tassel, hence breaking it ... I hope this Desmodium protects maize from stemborer and from birds .... I I will continue to observe this trend in the coming seasons. In future I will make some conclusion. (The PPT Farmer interview, April 2015, Dembi Gobu, Bako Tibe)

However, this observation did not last long. Towards the end of season, the birds started attacking the maize crop, but the effect was less, because the cobs had already matured and it was difficult for the birds to feed on mature maize cobs. This was an advantage to the farmer. This keenness of the farmers to make observation and try to make sense of it either by conducting own research or engaging researchers for further discussions was a significant step towards appreciating the technology. This was not only in addressing the pest problem, but also an opportunity for learning by seeking answers to "new observations" made. For example, why did the birds not recognize the maize earlier? Was maize made invisible as a result of intercropping with Desmodium? Some of these questions were raised by the farmers based on the observations made for the first time and during the first cropping season. However, for certainty, they decided to continue to follow on this observation for some time and during subsequent seasons. They hoped that after 2-3 years of continuous cropping, they would have formed an opinion based on the long-term observations on the performance of the technology and even make recommendations for changes or adaptations. In the meantime, it came out from the discussions that there is no scientific method so far for scaring or controlling birds. Locally, the farmers use a cassette tape ribbon which they wind along the borders of the maize field. The hissing sound and reflection produced by the ribbon due to the winds blowing is used to scare off the birds. However, this is only effective for small plots of land of $<0.5$ ha. On the larger fields, they rely on manually scaring the birds away mainly by throwing stones into the maize plantation. This lasts for about two weeks, after which the maize cobs mature and the birds cannot manage to feed on them. However, during off-season crop, the population of birds is too high and feeding on the grain can be intense within a very short period, causing huge losses to the farmers. 


\section{Conclusions}

The article shows that effective collaborative leadership coupled with social empowerment provides a chance, especially for the farmer stakeholders, to participate in the learning and decision-making processes by enabling them to contribute skills towards the development, refinement and adaptation of Push-Pull Technology. The personal interest among the researchers and other stakeholders is linked with the newness and first-time introduction of the technology to the study area to partake in its emergent opportunities and relationships. Although the perennial nature of cropping in the PPT provides opportunities for empowerment through continuous interaction and learning, it requires committed leadership and institutional engagements starting from the initial stages of planning and implementation, involving the researchers and other stakeholders. In the transdisciplinary research process, leadership roles taken by farmers is empowering in terms of their ability to reflect on their own practices and drawing on scientific explanations from researchers. It also enables them to take lead in new technology implementation and information sharing in a free and easy manner with fellow farmers and other stakeholders. Even though the implementation process was undertaken jointly; the different stakeholders represented their respective interest groups. That means that collaboration with "personally" committed leadership is most likely to contribute to the sustainability of the PPT activities when the personal interests are met first or understood well. The immediate PPT benefits and assurances will sustain the stakeholder interests and gain their trust for continued interaction and learning or follow-up on the PPT. Market forces and the involvement of the private sector players also have a role to play in this, as shown by the interests of individual farmers and traders in Desmodium and Brachiaria seed production, collection and distribution.

The findings show that, in a situation where there are conflicts, either of professional or disciplinary nature or practice-based, they should be embraced and become opportunities for in-depth learning, finding solutions and adaptation, rather than being sources of contradictions or misunderstandings about the new technology. That means new challenges which come with such a new technology should be addressed and developed in situ and used as the essential points of learning for further research, thus refining and improving its practical use.

The sustainability of the PPT activities and the transdisciplinary processes require longer term evaluation studies. Consequently, a follow-up to this study should be considered to document the changes which occurred. This is based on the fact that the introduction of the PPT, although seems positive and progressive, was not immediately accepted by all the stakeholder groups.

Author Contributions: G.K. and A.-K.H. supported in designing the study, and actively participated in its implementation and provided guidance in data analysis. C.A.O.M. and C.B. contributed to the provision of materials and logistics for field research and the data collection. I.M.N. conceived the study, collected and analyzed the data, and wrote-supported by the co-authors—-the article.

Funding: The authors highly appreciate the scholarships and financial support received from The German Ministry for Economic Cooperation and Development (BMZ) through the BiomassWeb project (https://biomassweb.org) component of the International Center for Insect Physiology and Ecology (icipe) for the entire study.

Acknowledgments: Special thanks go to the farmers, Ministry of Agriculture officials and researchers from the Center for Development research (ZEF), University of Bonn and the Ethiopian Institute of Agricultural Research (EIAR) who provided guidance and technical support for the study.

Conflicts of Interest: No conflict of interest was reported by the authors.

\section{References}

1. Bracken, L.J.; Bulkeley, H.A.; Whitman, G. Transdisciplinary research: Understanding the stakeholder perspective. J. Environ. Plan. Manag. 2015, 58, 1291-1308. [CrossRef]

2. Lang, D.J.; Wiek, A.; Bergmann, M.; Stauffacher, M.; Martens, P.; Moll, P.; Swilling, M.; Thomas, C.J. Transdisciplinary research in sustainability science: Practice, principles, and challenges. Sustain. Sci. 2012, 7, 25-43. [CrossRef] 
3. Wright Morton, L.; Eigenbrode, S.D.; Martin, T.A. Architectures of adaptive integration in large collaborative projects. Ecol. Soc. 2015, 20. [CrossRef]

4. Hirsch Hadorn, G.; Hoffmann-Riem, H.; Biber-Klemm, S.; Grossenbacher-Mansuy, W.; Joye, D.; Pohl, C.; Wiesmann, U.; Zemp, E. (Eds.) Handbook of Transdisciplinary Research, Springer: Dordrecht, Netherlands; Springer: Berlin, Germany, 2008; ISBN 978-1-4020-6700-6. Available online: https:/ /www.springer.com/gp / book/9781402066986 (accessed on 4 April 2018).

5. Hoppe, R. Rethinking the Science-Policy Nexus: From Knowledge Utilization and Science Technology Studies to Types of Boundary Arrangements. Poiesis Prax. 2005, 3, 199-215. [CrossRef]

6. Nowotny, H.; Scott, P.; Gibbons, M. Re-thinking science. In Re-Thinking Science: Knowledge and the Public in an Age of Uncertainty; Polity Press: Cambridge, UK, 2001.

7. Stauffacher, M.; Flüeler, T.; Krütli, P.; Scholz, R. Analytic and Dynamic Approach to Collaboration: A Transdisciplinary Case Study on Sustainable Landscape Development in a Swiss Prealpine Region. Syst. Pract. Action Res. 2008, 21, 409-422. [CrossRef]

8. Bunders-Aelen, J.G.F.; Broerse, J.E.W.; Keil, F.; Pohl, C.; Scholz, R.W.; Zweekhorst, M.B.M. How can transdisciplinary research contribute to knowledge democracy. In Knowledge Democracy-Consequences for Science, Politics and Media; In't Veld, R., Ed.; Springer: Heidelberg, Germany, 2010; pp. 125-152.

9. Popa, F.; Guillermin, M.; Dedeurwaerdere, T. A pragmatist approach to transdisciplinarity in sustainability research: From complex systems theory to reflexive science. Futures 2015, 65, 45-56. [CrossRef]

10. Siebenhüner, B. Social learning and sustainability science: Which role can stakeholder participation play? Int. J. Sustain. Dev. 2004, 7, 146-163. [CrossRef]

11. Mobjörk, M. Centrum för Urbana och Regionala Studier. In Crossing Boundaries: The Framing of Transdisciplinarity; Örebro Universitet: Örebro, Sweden, 2009.

12. Mobjörk, M. Consulting versus participatory transdisciplinarity: A refined classification of transdisciplinary research. Futures 2010, 42, 866-873. [CrossRef]

13. Harris, F.; Lyon, F. Transdisciplinary Environmental Research: A Review of Approaches to Knowledge Co-production. Available online: http://www.thenexusnetwork.org/wp-content/uploads/2014/08/ Harris-and-Lyon_pg.pdf (accessed on 8 July 2018).

14. Reid, R.S.; Nkedianye, D.; Said, M.Y.; Kaelo, D.; Neselle, M.; Makui, O.; Onetu, L.; Kiruswa, S.; Kamuaro, N.O.; Kristjanson, P.; et al. Evolution of models to support community and policy action with science: Balancing pastoral livelihoods and wildlife conservation in savannas of East Africa. Proc. Natl. Acad. Sci. USA 2016, 113, 4579-4584. [CrossRef] [PubMed]

15. Schäpke, N.; Omann, I.; Wittmayer, J.M.; van Steenbergen, F.; Mock, M. Linking transitions to sustainability: A study of the societal effects of transition management. Sustainability 2017, 9, 737. [CrossRef]

16. Crosby, B.C.; Bryson, J.M. Leadership for the Common Good: Tackling Public Problems in a Shared-Power World, 2nd ed.; Jossey-Bass: San Francisco, CA, USA, 2005.

17. Bushe, G.R. Clear Leadership: Sustaining Real Collaboration and Partnership at Work; Davies-Black Pub: Mountain View, CA, USA, 2009.

18. Gray, B. Enhancing Transdisciplinary Research through Collaborative Leadership. Am. J. Prev. Med. 2008, 35, 124-132. [CrossRef] [PubMed]

19. Archer, D.; Cameron, A. Collaborative Leadership: How to Succeed in an Interconnected World; Elsevier/ Butterworth-Heinemann: Amsterdam, The Netherland, 2009.

20. Chrislip, D.D. The Collaborative Leadership Fieldbook: A Guide for Citizens and Civic Leaders; Jossey-Bass: San Francisco, CA, USA, 2002.

21. Frydman, B.; Wilson, I.; Wyer, J. The Power of Collaborative Leadership: Lessons for the Learning Organization; Butterworth-Heinemann: Boston, MA, USA, 2000.

22. Linden, R.M. Working across Boundaries: Making Collaboration Work in Government and Nonprofit Organizations, 1st ed.; Jossey-Bass: San Francisco, CA, USA, 2002.

23. Stokols, D. Toward a Science of Transdisciplinary Action Research. Am. J. Commun. Psychol. 2006, 38, 79-93. [CrossRef] [PubMed]

24. Pedrosa, A. Motivating stakeholders for co-created innovation. Open Sour. Bus. Resour. 2009. Available online: http:/ / timreview.ca/article/311 (accessed on 4 April 2018). 
25. Siarta, S.; Blochb, R.; Knierima, A.; Bachingerb, J. Development of Agricultural Innovations in Organic Agriculture to Adapt to Climate Change-Results from a Transdisciplinary R\&D Project in North-eastern Germany. In Proceedings of the 10th European IFSA Symposium, International Farming Systems Association, Aarhus, Denmark, 1-4 July 2012.

26. Stokols, D.; Fuqua, J.; Gress, J.; Harvey, R.; Phillips, K.; Baezconde-Garbanati, L.; Unger, J.; Palmer, P.; Clark, M.A.; Colby, S.M.; et al. Evaluating transdisciplinary science. Nicot. Tob. Res. 2003, 5, S21-S39. [CrossRef] [PubMed]

27. Pohl, C. What is progress in transdisciplinary research? Futures 2011, 43, 618-626. [CrossRef]

28. Siebenhüner, B.; Romina, R.; Franz, E. Social Learning Research in Ecological Economics: A Survey. Environ. Sci. Policy 2016, 55, 116-126. [CrossRef]

29. Godemann, J. Knowledge Integration: A Key Challenge for Transdisciplinary Cooperation. Environ. Educ. Res. 2008, 6, 625-641. [CrossRef]

30. EU SCAR. Agricultural Knowledge and Innovation Systems in Transition-A Reflection Paper; Standing Committee on Agricultural Research (SCAR); Collaborative Working Group on Agricultural Knowledge and Innovation Systems (AKIS); European Commission \& Directorate-General for Research and Innovation: Brussels, Belgium, 2012.

31. Berhanu, K.; Poulton, C. The political economy of agricultural extension policy in Ethiopia: Economic growth and political control. Dev. Policy Rev. 2014, 32, 197-213. [CrossRef]

32. Abate, T.; Shiferaw, B.; Gebeyehu, S.; Amsalu, B.; Negash, K.; Assefa, K.; Million, E.; Aliye, S.; Shiferaw, B.; Abate, T.; et al. A systems and partnership approach to agricultural research for development: Lessons from Ethiopia. Outlook Agric. J. 2011, 40, 213-220. [CrossRef]

33. Ministry of Finance and Economic Development (MoFED). Federal Democratic Republic of Ethiopia: Sustainable Development and Poverty Reduction Program; MoFED: Addis Ababa, Ethiopia, 2002.

34. United Nations Development Programme (UNDP). African Economic Outlook 2015: Regional Development and Spatial Inclusion; OECD Publishing: Paris, France, 2015.

35. Elias, A.; Nohmi, M.; Yasunobu, K.; Ishida, A. Effect of Agricultural Extension Program on Smallholders' Farm Productivity: Evidence from Three Peasant Associations in the Highlands of Ethiopia. J. Agric. Sci. 2013, 5, 163. [CrossRef]

36. World Bank. Enhancing Agricultural Innovation: How to Go Beyond the Strengthening of Research Systems; The International Bank for Reconstruction and Development: Washington, DC, USA, 2006.

37. Star, S.L.; Griesemer, J.R. Institutional Ecology, Translations and Boundary Objects: Amateurs and Professional in Berkeley's Museum of Vertebrate Zoology, 1907-39. Soc. Stud. Sci. 1989, 19, 387-420. [CrossRef]

38. Rosenfield, P. The potential of transdisiplinary research for sustaining and extending linkages between the health and social sciences. Soc. Sci. Med. 1992, 35, 1343-1357. [CrossRef]

39. Ul-Hassan, M.; Hornidge, A.-K.; van Veldhuizen, L.; Akramkhanov, A.; Rudenko, I.; Djanibekov, N. Participatory Testing and Adaptation of Agricultural Innovations in Uzbekistan-Guidelines for Researchers and Practitioners; Center for Development Research (ZEF), University of Bonn: Bonn, Germany, 2011.

40. Chamberlain, K.; Khan, Z.R.; Pickett, J.A.; Toshova, T.; Wadhams, L.J. Diel periodicity in the production of green leaf volatiles by wild and cultivated host plants of stemborer moths, Chilo partellus and Busseola fusca. J. Chem. Ecol. 2006, 32, 565-577. [CrossRef] [PubMed]

41. Demeke, M. Analysis of Incentives and Disincentives for Maize in Ethiopia; Technical Notes Series; MAFAP, FAO: Rome, Italy, 2012.

42. Statistical Central Agency (CSA). Agricultural Sample Survey 2010/2011 (September-December 2010); Report on Area and Production of Major Crops; CSA: Addis Ababa, Ethiopia, 2011.

43. Smale, M.; Byerlee, D.; Jayne, T. Maize revolutions in sub-Saharan Africa. In An African Green Revolution; Springer: Berlin, Germany, 2013; pp. 165-195. Available online: http:/ /link.springer.com/chapter/10.1007/ 978-94-007-5760-8_8 (accessed on 4 April 2018).

44. Mantel, S.; Van Engelen, V.W.P. Assessment of the impact of water erosion on productivity of maize in Kenya: An integrated modelling approach. Land Degrad. Dev. 1999, 10, 577-592. [CrossRef]

45. Oswald, A. Striga control Technologies and their dissemination. Crop Prot. 2005, 24, 333-342. [CrossRef]

46. Kfir, R.; Overholt, W.A.; Khan, Z.R.; Polaszek, A. Biology and management of economically important lepidopteran cereal stemborers in Africa. Annu. Rev. Entomol. 2002, 47, 701-731. [CrossRef] [PubMed] 
47. Midega, C.A.O.; Bruce, T.J.A.; Pickett, J.A.; Pittchar, J.O.; Murage, A.; Khan, Z.R. Climate-adapted companion cropping increases agricultural productivity in East Africa. Field Crops Res. 2015, 180, 118-125. [CrossRef]

48. Midega, C.A.O.; Pittchar, J.; Salifu, D.; Pickett, J.A.; Khan, Z.R. Effects of mulching, N-fertilization and intercropping with Desmodium uncinatum on Striga hermonthica infestation in maize. Crop Prot. 2013, 44, 44-49. [CrossRef]

49. Midega, C.A.; Wasonga, C.J.; Hooper, A.M.; Pickett, J.A.; Khan, Z.R. Drought-Tolerant Desmodium Species Effectively Suppress Parasitic Striga Weed and Improve Cereal Grain Yields in Western Kenya. Crop Prot. 2017, 98, 94-101. [CrossRef] [PubMed]

50. Khan, Z.R.; Midega, C.A.O.; Wadhams, L.J.; Pickett, J.A.; Mumuni, A. Evaluation of Napier grass (Pennisetum purpureum) varieties for use as trap plants for the management of African stemborer (Busseola fusca) in a push-pull strategy. Entomol. Exp. Appl. 2007, 124, 201-211. [CrossRef]

51. Khan, Z.R.; Pickett, J.A.; Wadhams, L.J.; Hassanali, A.; Midega, C.A.O. Combined control of Striga hermonthica and stem borers by maize-Desmodium spp. intercrops. Crop Prot. 2006, 25, 989-995. [CrossRef]

52. Tsanuo, M.K.; Hassanali, A.; Hooper, A.M.; Khan, Z.R.; Kaberia, F.; Pickett, J.A.; Wadhams, L.J. Isoflavanones from the allelopathic aqueous root exudates of Desmodium uncinatum. Phytochemistry 2003, 64, 265-273. [CrossRef]

53. Khan, Z.R.; Pickett, J.A.; Van den Berg, J.; Wadhams, L.J.; Woodcock, C.M. Exploiting chemical ecology and species diversity: stem borer and striga control in maize in Kenya. Pest Manag. Sci. 2000, 56, 957-962. [CrossRef]

54. Khan, Z.R.; Hassanali, A.; Overholt, W.; Khamis, T.M.; Hooper, A.M.; Pickett, A.J.; Wadhams, L.J.; Woodcock, C.M. Control of witchweed Striga hermonthica by intercropping with Desmodium spp., and the mechanism defined as allelopathic. J. Chem. Ecol. 2002, 28, 1871-1885. [CrossRef] [PubMed]

55. Khan, Z.R.; Midega, C.A.O.; Amudavi, D.M.; Njuguna, E.M.; Wanyama, J.W.; Pickett, J.A. Economic performance of the "Push-pull" technology for stemborer and Striga control in smallholder farming systems in western Kenya. Crop Prot. 2008, 27, 1084-1097. [CrossRef]

56. Habermann, B.; Misganaw, B.; Peloschek, F.; Dessalegn, Y.; Yihenew, G. Inter-and Transdisciplinary Research Methods in Rural Transformation Case Studies in Northern Ethiopia; BOKU: Vienna, Austria, 2013. [CrossRef]

57. Hornidge, A.-K.; Ul-Hassan, M.; Mollinga, P.P. 'Follow the Innovation'-A joint experimentation and learning approach to transdisciplinary innovation research. ZEF Work. Paper Ser. 2009, 39. [CrossRef]

58. Hornidge, A.-K.; Ul-Hassan, M.; Mollinga, P.P. Transdisciplinary innovation research in Uzbekistan-One year of 'Follow-the-Innovation'. Dev. Pract. 2011, 21, 834-847. [CrossRef]

59. Allen, W.; Ogilvie, S.; Blackie, H.; Smith, D.; Sam, S.; Doherty, J.; McKenzie, D.; Ataria, J.; Shapiro, L.; MacKay, J.; et al. Bridging Disciplines, Knowledge Systems and Cultures in Pest Management. Environ. Manag. 2014, 53, 429-440. [CrossRef] [PubMed]

60. Kohler, T.; Fueller, J.; Matzler, K.; Stieger, D. Co-creation in virtual worlds: The design of the user experience. MIS Q. 2011, 35, 773-788. [CrossRef]

61. Bortz, J.; Döring, N. Forschungsmethoden und Evaluation für Human-und Sozialwis-Senschaftler; Springer: Berlin/Heidelberg, Germany, 2003.

62. Miller, T.R.; Baird, T.D.; Littlefield, C.M.; Kofinas, G.; Chapin, F.; Redman, C.L. Epistemological pluralism: Reorganizing interdisciplinary research. Ecol. Soc. 2008, 13, 46. [CrossRef]

63. Freeman, R.E. Strategic Management: A Stakeholder Approach; Pitman: Boston, MA, USA, 1984.

64. Lundvall, B.-Å. (Ed.) National Systems of Innovation: Towards a Theory of Innovation and Interactive Learning; Frances Pinter: London, UK, 1992.

65. Nelson, R.R. (Ed.) National Innovation Systems: A Comparative Analysis; Oxford University Press: Oxford, UK, 1993.

66. Edquist, C. Systems of Innovation: Technologies, Institutions and Organizations; Pinter Publishers/Cassell Academic: London, UK, 1997.

67. Abate, T.; Shiferaw, B.; Menkir, A.; Wegary, D.; Kebede, Y.; Tesfaye, K.; Kassie, M.; Bogale, G.; Tadesse, B.; Keno, T. Factors that transformed maize productivity in Ethiopia. Food Secur. 2015, 7, 965-981. [CrossRef]

68. Abdissa, G.; Ethiopian Agricultural Research Organization; International Maize and Wheat Improvement Center (Eds.) Farmers' Maize Seed Systems in Western Oromia, Ethiopia; International Maize and Wheat Improvement Center: Addis Ababa, Ethiopia, 2001. 
69. Stellmacher, T.; Grote, U. Forest Coffee Certification in Ethiopia: Economic Boon or Ecological Bane? ZEF Working Paper Series No. 76; University of Bonn, Center for Development Research (ZEF): Bonn, Germany, 2011.

70. Assefa, G.A. Development of maize stalk borer, Busseola fusca (Fuller), in wild host plants in Ethiopia. J. Appl. Entomol. 1998, 106, 390-395.

71. Belay, D.; Foster, J.E. Efficacies of habitat management techniques in managing maize stemborers in Ethiopia. Crop Prot. 2010, 29, 422-428. [CrossRef]

72. Getu, E.; Overholt, W.A.; Kairu, E.; Omwega, C.O. Status of stemborers and their management in Ethiopia. In Proceedings of the Integrated Pest Management, Kampala, Uganda, 8-12 September 2002.

73. Hurni, H. Agroecological Belts of Ethiopia. Explanatory Notes on Three Maps at a Scale of 1, 1. Soil Conservation Research Programme, Research Report. J. Technol. Glob. 1998, 2, 279-287.

74. Deneke, T.T.; Gulti, D. Agricultural Research and Extension Linkages in the Amhara Region, Ethiopia. In Technological and Institutional Innovations for Marginalized Smallholders in Agricultural Development; Gatzweiler, F.W., von Braun, J., Eds.; Springer: Cham, Switzerland, 2016; pp. 113-124.

75. Wenger, E.; McDermott, R.; Snyder, W. Cultivating Communities of Practice: A Guide to Managing Knowledge; Harvard Business School Press: Boston, MA, USA, 2002.

76. Amudavi, D.M.; Khan, Z.R.; Wanyama, J.M.; Midega, C.A.O.; Pittchar, J.; Hassanali, A.; Pickett, J.A. Evaluation of farmers' field days as a dissemination tool for push-pull technology in Western Kenya. Crop Prot. 2009, 28, 225-235. [CrossRef]

77. Amudavi, D.M.; Khan, Z.R.; Wanyama, J.M.; Midega, C.A.O.; Pittchar, J.; Nyangau, I.M.; Hassanali, A.; Pickett, J.A. Assessment of technical efficiency of farmer teachers in the uptake and dissemination of push-pull technology in Western Kenya. Crop Prot. 2009, 28, 987-996. [CrossRef]

78. Rogers, E.M. Diffusion of Innovations, 5th ed.; Free Press: New York, NY, USA, 2003.

79. Akkerman, S.F.; Bakker, A. Boundary Crossing and Boundary Objects. Rev. Educ. Res. 2011, 81, 132-169. [CrossRef]

80. Anseeuw, W.; Boche, M.; Breu, T.; Giger, M.; Lay, J.; Messerli, P. Transnational Land Deals for Agriculture in the Global South: Analytical Report Based on the Land Matrix Database; Geographica Bernensia; CDE/CIRAD/GIGA: Bern/Montpellier/Hamburg, Germany, 2012.

81. Medlin, B.D. The Factors that May Influence a Faculty Member's Decision to Adopt Electronic Technologies in Instruction. Ph.D. Thesis, Virginia Polytechnic Institute and State University, Blacksburg, VA, USA, 2001.

82. Cross, R.L.; Parker, A.; Sasson, L. (Eds.) Networks in the Knowledge Economy; Oxford University Press: New York, NY, USA, 2003.

83. Suchman, L. Working relations of technology production and use. Comput. Supported Cooperative Work 1994, 2, 21-39. [CrossRef]

84. Cundill, G.; Roux, D.J.; Parker, J.N. Nurturing communities of practice for transdisciplinary research. Ecol. Soc. 2015, 20, 22. [CrossRef]

85. Berger-González, M.; Stauffacher, M.; Zinsstag, J.; Edwards, P.; Krütli, P. Transdisciplinary Research on Cancer-Healing Systems between Biomedicine and the Maya of Guatemala: A Tool for Reciprocal Reflexivity in a Multi-Epistemological Setting. Qual. Health Res. 2016, 1, 77-91. [CrossRef] [PubMed]

(C) 2018 by the authors. Licensee MDPI, Basel, Switzerland. This article is an open access article distributed under the terms and conditions of the Creative Commons Attribution (CC BY) license (http://creativecommons.org/licenses/by/4.0/). 